\title{
Why has for-profit colleges' share of higher education expanded so rapidly? Estimating the responsiveness to labor market changes
}

\author{
Authors: Gregory Gilpin, Joseph Saunders, \& Christiana Stoddard
}

NOTICE: this is the author's version of a work that was accepted for publication in Economics of Education Review. Changes resulting from the publishing process, such as peer review, editing, corrections, structural formatting, and other quality control mechanisms may not be reflected in this document. Changes may have been made to this work since it was submitted for publication. A definitive version was subsequently published in Economics of Education Review, [VOL. 45, (April 2015)] DOI\# 10.1016/i.econedurev.2014.11.004

Gilpin, Gregory A., Joseph Saunders, and Christiana Stoddard. 'Why Has for-Profit Colleges' Share of Higher Education Expanded so Rapidly? Estimating the Responsiveness to Labor Market Changes." Economics of Education Review 45 (April 2015): 53-63.

doi:10.1016/j.econedurev.2014.11.004

Made available through Montana State University's ScholarWorks scholarworks. montana.edu 


\title{
Why has for-profit colleges' share of higher education expanded so rapidly? Estimating the responsiveness to labor market changes
}

\author{
Gregory A. Gilpin \& Christiana Stoddard: Department of Agricultural Economics and Economics, Montana State University, Bozeman, MT 59717 \\ Joseph Saunders: Accenture LLP, 800 Connecticut Avenue, Ste. 600, Washington, DC 20006
}

\begin{abstract}
Over the last two decades, for-profit colleges (FPCs) have substantially increased their share of the higher education market. One potential explanation is that FPC sector may be more responsive to labor market changes than public competitors. Using panel datasets of Associate's degree students, we examine the effects of changes in labor market conditions across various employment fields on enrollment and degree completion in related majors. The results indicate that enrollment and degree completion in the FPC sector is positively related to employment growth and wages in related occupations, while public institutions remain largely unresponsive. Heterogeneity analysis reveals that these relationships are similar across groups of students by gender and ethnicity. Furthermore, the results also indicate that students in public institutions are non-responsive to changes in labor markets associated with requiring an Associate's or Bachelor's degree.
\end{abstract}

\section{Introduction}

For-profit colleges (FPCs) are one of the most rapidly expanding types of higher education providers in the United States. Many of these schools focus on two-year programs, and over the past two decades they have accounted for much of the growth in Associate's degrees. FPCs doubled their enrollment of Associate's degree seeking students between 1995-1996 and 2010-2011, a rate of increase that was three times faster than in public community colleges. The number of Associate's degrees awarded grew even faster, with a growth rate at FPCs that was six times faster than that at community colleges, resulting in FPCs increasing their share of Associates degrees awarded from $10 \%$ to $22 \%$ between $1995-$ 1996 and 2010-2011.
Costs and the type of education services provided by FPCs differ from their public competitors. Knapp, Kelly-Reid, and Ginder (2011) report the average annual tuition difference between public community colleges and for-profit colleges to be approximately $\$ 12,000$ (see Kofoed, 2014 for analysis on financial aid allocation). Typically, for-profit institutions have had more limited program offerings, with many smaller FPCs specializing in only one or two programs. In contrast, public two-year institutions typically offer a wider spectrum of programs, with greater availability of general studies and liberal arts programs. For example, during the 2011-2012 academic school year, FPCs awarded $31 \%$ of all degrees in health fields, $25 \%$ in business fields, and $9 \%$ in computer and information sciences fields, while $42 \%$ of public two-year 


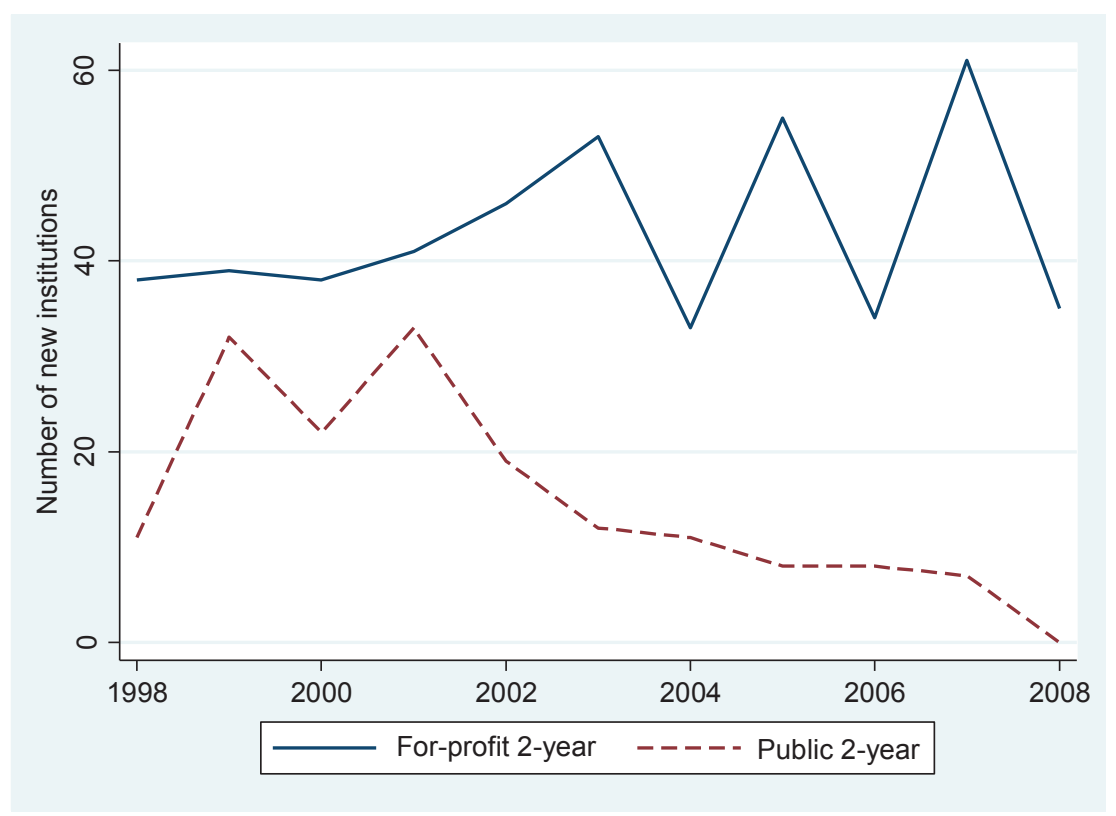

Fig. 1. Number of new public and for profit two-year degree granting institutions, 1998-2008. Source: Author calculations based on Integrated Postsecondary Education Data System (IPEDS).

degrees were awarded in liberal arts, humanities, or general education fields (Digest of Education Statistics, 2012, Table 292).

FPCs have also rapidly expanded into new fields. Little literature exists to rigorously compare the barriers to entry in the higher education market and how these barriers compare across for-profit and public institutions. Data on new institutions and programs suggest that FPCs are much more likely to be entrants. Fig. 1 shows the number of new twoyear institutions from 1998 through 2008. Although there are substantially more public institutions than private, between 35 and 60 new two-year FPCs opened each year during this decade, on average at least twice as many as the number of public entrants in the same year. Fig. 2 displays this information by field of study. ${ }^{2}$ A new field of study is defined as one where no related majors existed in previous years. Fig. 2 shows that in each year between 1998 and 2008, roughly 5\% of the fields of study at public institutions are new introductions, while on average between 10 and 20\% of the fields of study are new introductions at for-profit institutions. ${ }^{3}$

For-profit colleges have structural features that may allow them to quickly adapt to changing economic conditions, generating new entry. For example, FPCs typically have a different governance structure than public institutions, with more defined stakeholder interests, fewer tenured faculty, and physical and financial structures that allow more flexibility. One potential explanation for the expansion of FPCs may be greater program flexibility related to labor market

\footnotetext{
2 Majors are aggregated into 12 broad fields of study (e.g., business, education, legal studies, etc.), as defined in more detail below.

3 Schools must establish a Program Participation Agreement with the US Department of Education to be a Title IV institution by meeting eligibility requirements of state licensure, institutional accreditation, standards of financial responsibility and administrative capability. A participating school must also comply with various state and federal laws.
}

conditions. This could allow them to capture more of each programs' enrollment share, while public institutions may be not be as nimble in adjusting their program offerings.

Does some of the growth of FPCs represent differences in responsiveness to labor market conditions, or does this simply reflect an overall shift towards this new institutional option? To evaluate this, we examine enrollment and degree completion in various Associate's degree programs across states and over time in response to labor market conditions within related occupations. Although there is a growing body of research on individual's choice to enroll at FPCs versus community colleges, with particular emphasis on student characteristics and tuition at competing schools (see Cellini, 2009; Chung, 2012; Deming, Goldin, \& Katz, 2012; Turner, 2003), to our knowledge there is little research exploring how changes in the labor market conditions affect the share of students at FPCs. ${ }^{4}$

Following the literature, we examine the Associate's degree level and restrict the comparison group to two-year public institutions (i.e., community colleges). ${ }^{5}$ We focus on Associate's degrees for several reasons. First, certificate programs are much more heterogeneous, making it more difficult to isolate the relative roles of for-profit or public institutional status. Focusing on two-year degree granting institutions limits the analysis to institutions that are fairly comparable along many other dimensions. Second, many of the concerns about

\footnotetext{
4 The closest research is Turner (2003) who studies the effect of local unemployment rates on the rate of enrollment at FPCs. The research finds that enrollment at for-profit institutions are sensitive to changes in the local economic conditions, but does not provide empirical analysis on whether public competitors are also influenced. Thus, the relative responsiveness is not estimated.

5 The FPC literature uses community colleges as a comparison group to reduce selection bias (see Chung 2008; Cellini 2009,2012; Deming, Goldin, and Katz 2012).
} 


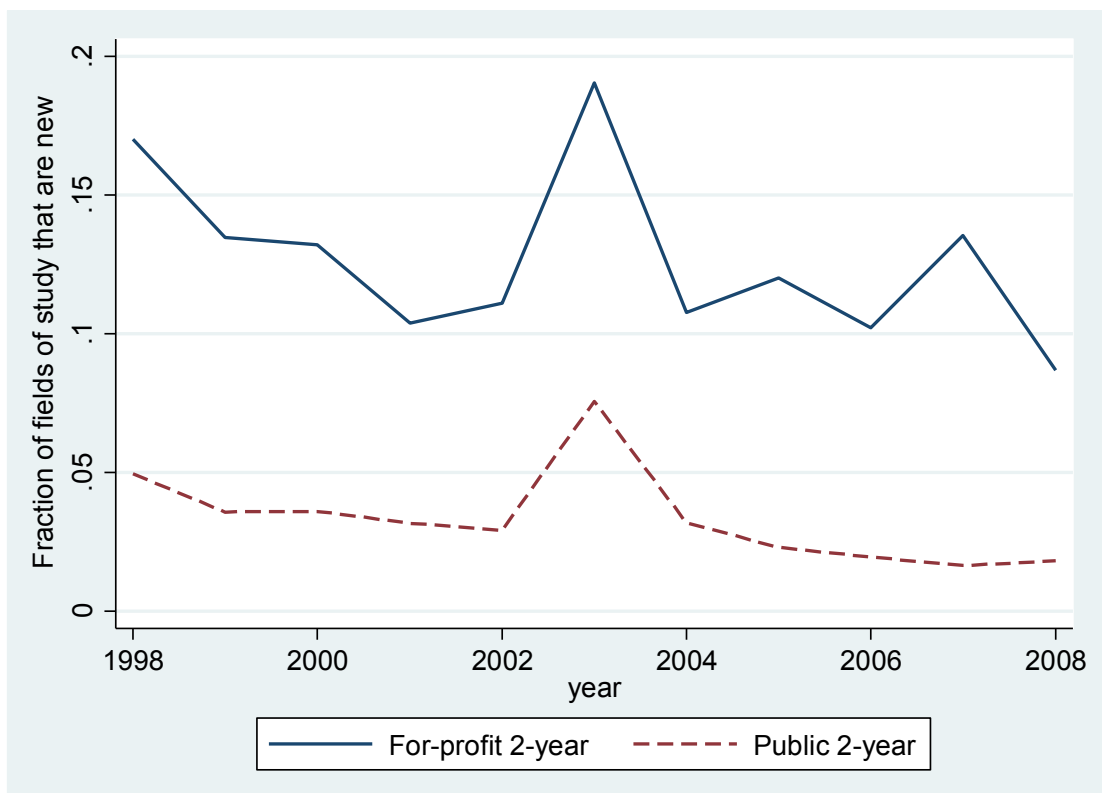

Fig. 2. Fraction of fields of study that are new introductions, two-year for-profit and public Degree Granting Institutions,1998-2008. Source: Author calculations based on Integrated Postsecondary Education Data System (IPEDS).

FPCs relate to high levels of debt their students incur, levels that are obviously higher for two-year programs than shorter duration certificates. These concerns have received increasing attention as FPCs have expanded into more advanced levels of education and their students have become recipients of federal financial aid. Accordingly, we only examine Title IV eligible institutions, as other institutions are not eligible for the same types of federal financial aid. However, the penetration of FPCs into four-year and graduate programs has been relatively recent, limiting our ability to use trends over time for these institutions.

We study the impacts of labor market conditions on both enrollment and degree completion. One concern with studying enrollment is that the results may be susceptible to the confounding influence of community college students taking courses for non-employment reasons. Studying degree completion provides additional evidence that a confounding effect is not driving the results. We capture contemporaneous and recent state-level labor market conditions across various employment fields using the average employment growth and the real wage level over the previous three years prior to enrollment or degree completion. Using the average over a three-year time span permits an evaluation of the changes in employment conditions when individuals were deciding to enroll and also smoothes out transitory shocks. These two measures capture different potential labor market attributes that may affect students. Betts (1996), Freeman and Hirsch (2008), Webbink and Hartog (2004) have examined student responsiveness to occupational employment opportunities as well as wage opportunities and find both to be distinctly relevant measures.

The panel data analyses indicate that enrollment in Associate's degrees and degree completions are more responsive to changes in employment conditions of related occupations at FPCs than at community colleges. Specifically, a $1 \%$ increase in employment growth in an occupational field is correlated with expanding enrollment shares in related majors at FPCs of about 3.2 percentage points and an increase in degree completion at FPCs of 1.5 percentage points. While these appear to be large responses, it is important to note that the magnitude of the results indicate a change in flow of new hires within occupations; although new hires are a small proportion of total employment, entrants with new degrees may be a substantive share of new hires. ${ }^{6}$ The effect of employment growth at community colleges is much smaller, only 0.5 percentage points, and is negatively related. Additionally, a $1 \%$ increase in an occupational field's real wage is correlated with an expanded enrollment share in majors in related fields of study of about 5.0 percentage points at FPCs. Wage effects at community colleges are about two-thirds as large.

We explore the robustness of these results using a variety of specifications accounting for permanent differences in unobserved characteristics of FPCs, states, and time periods as well as differential effects across occupational fields, prevalence of FPCs, availability of program offerings, labor market conditions by level of education, and student demographic characteristics. We find the pattern of greater responsiveness at FPCs is preserved.

\section{Background: differences in for-profit colleges and public community colleges}

Currently there are approximately 3.3 million students enrolled at FPCs (see Digest of Education Statistics, 2013, Table 301.1). The FPC sector contains a wide range of schools. Best known are the largest institutions that offer a wide array of programs, such as the University of Phoenix owned by the

\footnotetext{
${ }^{6}$ We thank a referee for pointing out this interpretation.
} 
Apollo group. The largest institutions account for the majority of enrollment at FPCs, with the top 15 institutions enrolling approximately $60 \%$ of all FPC students (Bennett, Lucchesi, \& Vedder, 2010). At the other end of the spectrum, there are hundreds of smaller FPCs that offer limited sets of programs. In a study of California FPCs, on average, each college offered four degrees or certificate programs and enrolled approximately 71 students (Cellini, 2005).

FPCs differ from public institutions in several key ways. First, the overall objectives of public colleges and FPCs are different. For example, 13 of the 15 largest for-profit college firms are publicly traded (Bennett et al., 2010), ${ }^{7}$ and therefore operate similarly to other publicly-traded firms who pursue profits and distribute dividends to shareholders. Second, the vast majority of FPCs' revenue (88\%) is derived from student tuition (Hentschke, 2011). While students do receive federal grants or subsidized loans to reduce their share of these tuition costs, only $7 \%$ of revenue is derived from government grants, contracts, and appropriations that flow directly to the institution. In contrast, direct government support accounts for approximately $53 \%$ of revenues at public community colleges in the form of state and local appropriations, while $35 \%$ is derived from student tuition, which may include tuition payments provided by federal grants or subsidized loans ("Community College Fact Sheet", 2012)..$^{8}$ Because public dollars for community colleges are specifically tied to the individual institution, as opposed to following the student to a range of institutions, community colleges have a mandate from voters to provide services for their local area. Consequently, community colleges typically have mission statements with diverse goals that address the broader interests of voters and area residents, including aiding developmental education, lifelong learning, university transfer, cultural enrichment, civic, personal, and cultural growth, community service, community prosperity, and community vitality. ${ }^{9}$ For-profit colleges have a more prominent objective of maintaining relationships with local businesses, often using Employer Advisory Boards or Industry Advisory Councils, and marketing these relationships to potential students (Hentschke, 2011).

The two school types also have different management structures. For-profit colleges typically have boards of directors that dictate decision making and operations to the instructors. In contrast, community colleges typically have shared faculty governance for decision making on curriculum development, peer evaluation, hiring, marketing, and compensation (Bailey, 2006; Hentschke, 2011). For-profit

\footnotetext{
7 The University of Phoenix is the largest for-profit college and currently enrolled 319,400 undergraduate students and a total of 380,800 students across many campuses and through online programs in 2011 ("Apollo Group, Inc." 2011). By contrast, Arizona State University, the largest public university by enrollment, had 58,404 undergraduates and a total of 72,254 students (About ASU, 2012).

8 While almost all students at FPCs take advantage of Federal student aid, revenue at FPCs is dictated by enrollment and not simply provisioned in legislation.

9 These mission statement excerpts are taken from various community colleges, including City College of San Francisco (CA), Cleveland State Community College (TN), Cloud County Community College, (KS), Collin College (TX), Cuyahoga Community College $(\mathrm{OH})$, Flathead Valley Community College (MT), Manchester Community College (CT), Nassau Community College (NY), Piedmont Virginia Community College (VA), and State College of Florida Manatee-Sarasota (FL).
}

colleges are also more likely to hire part-time and nontenured adjunct instructors, while faculty lines at community colleges are more likely to be full-time tenured positions. Kinser (2007) finds that only 3\% of faculty members at publicly-traded for-profit colleges have tenure, while $17.5 \%$ of community colleges' faculties are tenured and $42 \%$ of newly hired full-time faculty is tenure track. As a result, FPC boards of directors have fewer constraints for reducing or expanding programs, changing course offerings, or removing poor performing instructors.

The differences in funding sources may cause community colleges to be more susceptible to changes in the business cycle. Given the heavy reliance on local and state funds, revenues for community college are more likely to fall when local and state revenues decrease (Berger \& Kostal, 2002). This pro-cyclical business cycle effect is exacerbated by the fact that the demand for higher education can be countercyclical (Betts \& McFarland, 1995). If tuition increases are insufficient to cover the marginal costs of offering additional programs, this may reduce faculty size (e.g., through attrition) or cap program enrollment and courses, precisely when the demands for these programs are greatest. Since FPCs receive little direct government funding, instead receiving funds primarily through student tuition, revenues are more likely to increase during economic downturns. This is because student enrollment tends to be counter-cyclical (Betts \& McFarland, 1995; Black \& Sufi, 2002; Dellas \& Sakellaris, 2003; Sakellaris \& Spilimbergo, 2000). As a result, instructor and enrollment caps are less likely to be binding. ${ }^{10}$

For-profit colleges typically have a physical plant structure that is more adjustable than that of community colleges. For-profit colleges are more likely to lease space (often in commercial areas) at multiple locations throughout a region than to have a large central campus, which is more typical of a community college. Moreover, FPCs have expanded more rapidly online, holding $42 \%$ of the online higher education market share (Bennett et al., 2010).

As discussed above, research on the student choice to enroll at a FPC or a competing public institution has been established, with particular emphasis on the effects of student characteristics and costs of competing schools. Chung (2012) studies the decision to attend a FPC versus attending community colleges and finds that the students' choice is heavily influenced by student's socioeconomic background and parental involvement. Chung (2008) also finds that the local concentration of FPCs is also important. Cellini (2009) finds that expansion of federal grant programs, such as the Pell Grant program, increases entry of FPC institutions. However, these gains do not come at a loss to community college enrollment. Rather, both FPC and community college enrollment increase. Deming et al. (2012) find that, relative to comparable students who attended community colleges or other public or private non-profit institutions, FPCs educate a larger fraction of minority, disadvantaged, and older students. ${ }^{11}$

\footnotetext{
10 See Berger and Kostal (2002) for more detail on state appropriate supply constraints.

11 There is also a recent line of research studying whether the returns to a FPC education is different than that of a public competitor. The results are mixed with some finding a negative effect (Deming, Goldin, \& Katz, 2012; Lang \& Weinstein, 2012; Liu \& Belfield, 2014), no statistically significant
} 


\section{Empirical specification}

The previous literature suggests that both demand and supply characteristics of for-profit and community colleges may differ. The main empirical analysis examines the reduced form relationship between labor market conditions in a specific occupational field (e.g., health occupations) and Associate's degree enrollment and degree completion in related majors at different types of institutions. Specifically, the analysis examines whether enrollment and degree completion change when field-specific employment conditions in a state change, and if so, whether the change is statistically different between FPCs and community colleges. For example, when employment conditions in medical fields improve, does enrollment in medically-oriented Associate's degrees increase, and is the responsiveness greater at FPCs than at public institutions?

We assume that there is a market for educational programs in state $s$ at time $t$ that leads to gainful employment in occupational field $j$. To conduct the analyses, we restrict our attention to FPCs and public counterparts that are as comparable as possible. We compare Associate's degree-seeking students at FPCs to those at two-year public institutions, predominantly community colleges. While some public fouryear degree universities and non-profit private higher education institutions offer two-year degrees, they are excluded as students in these programs since they are less likely to be similar to Associate's degree-seeking students at FPCs. ${ }^{12}$ Additionally, certificate granting schools are much more heterogeneous, are not Title IV eligible, and are not well represented in national surveys of higher education. The focus on Associate's degree seeking students allows us to examine populations that are as similar as possible across public and for-profit entities.

The supply of educational program $j$ is a function of the costs of producing a set enrollment capacity. The production function includes the physical plant, instructors, and other human resources necessary to provide the program. Similar to standard production functions, inputs may be sticky in the short-run, but are fully adjustable in the long-run. Furthermore, the time to change inputs may be different across school types. When employment conditions become more favorable in employment field $j$, this affects demand for slots in educational programs in related majors. The resulting quantity change is related to the underlying demand and supply conditions.

The main empirical specification is a reduced form estimate:

$$
\begin{aligned}
\ln Y_{i j s t}= & \beta_{0}+\mathrm{EC}_{j s t} \times \beta_{1}+\mathrm{EC}_{j s t} \times \mathrm{FPC}_{i} \times \beta_{2}+X_{s t} \beta_{3} \\
& +\beta_{4} \times \ln T_{s t}+\mathrm{FPC}_{i}+\mu_{j}+\varepsilon_{i j s t}
\end{aligned}
$$

where the dependent variable, $\ln Y_{i j s t}$, is either the $\log$ of total enrollment or degree completion (specified in more detail below) at school type $i$ (either a FPC or two-year public

difference (Darolia, Koedel, Martorell, \& Perez-Arce, 2014; Lang \& Weinstein, 2013), or a positive effect (Cellini, 2012; Cellini \& Chaudhary, 2012).

12 While not reported, we also extend the analysis to include all two-year institutions (public and private) as well as all two-year and four-year public institutions. These analyses do not control for any potential selection bias however and are available from the authors upon request. institutions) for majors classified into field $j$ in state $s$ at time $t$. The vector $\mathrm{EC}_{j s t}$ includes employment condition variables, employment growth and the real wage level, in log form. These measures appear to be the most widely available to prospective students, and career counselors typically advise students on which fields are expanding and what average wages are in related occupations. We average both employment conditions over the current year and the previous two years. The variable $\mathrm{FPC}_{i}$ is a dummy variable for whether school type $i$ is a FPC. The vector $X_{s t}$ contains state-level control variables and $\mu_{j}$ is employment-field specific fixed effects. These fixed effects account for permanent differences in the proportion of an employment field's majors. For example, business-related majors tend to attract higher proportions of students. In addition, we include the log of total enrollment (or degree completions) for a state, $T_{s t}$, to permit a straightforward interpretation of the main coefficients of interest, $\beta_{1}$ and $\beta_{2}$. Lastly, $\varepsilon_{i j s t}$ is the error term, for which we use a variety of specifications as discussed below. ${ }^{13}$

This structure permits an examination of the aggregate of the school type choice and major choice of individuals by studying enrollment and degree completion at different institutions types across time, states, and fields. The aggregate approach of using totals within a state has a number of empirical advantages. First, the level of aggregation on the left-hand side and right-hand side are consistent. Given the fact that mobility, particularly for college-aged students, is relatively high within a state, it is likely that students respond to overall employment conditions within a state, rather than, for example, MSA-level conditions. Additionally, occupational field-specific employment conditions are measured most completely at the state level. ${ }^{14}$ Second, state-level analysis permits us to exploit a panel framework to control for selection using institution type fixed effects. The FPC choice literature suggests that students who enroll in FPCs likely differ from students who enroll in public institutions in systematic ways and these systematic differences can be controlled using appropriate statistical methods, i.e., institutiontype fixed effects. Without the use of these fixed effects, even using comparison students that are most similar to FPC students, such as community college students, does not assure that selection is properly controlled. ${ }^{15}$ Additionally, using occupational field-specific employment conditions along with state-fixed effects instead of general employment conditions assures that this effect is not confounded with other statelevel influences.

The coefficients of interest in this specification are $\beta_{1}$ and $\beta_{2}$. The coefficient $\beta_{1}$ represents the percentage change in enrollment or degree completion in majors at community

\footnotetext{
13 An alternative specification would be to use the share of total enrollment (or degree completions) as the dependent variable. This essentially restricts $\beta_{4}$ to be equal to one and moves $\ln T_{\text {st }}$ to the left-hand side. We have run regressions under both specifications and find that we generally cannot reject the null of a coefficient equal to one. This implies that the interpretation of the other coefficients remains unchanged under either specification.

14 Some metro-level employment conditions are available but not for all occupational fields and only for large metropolitan areas. An analysis at a more disaggregate level would lose much data and would not be representative of the national sample.

15 For other discussions of aggregation and selection, see Card and Krueger (1996) and Moffit (1995).
} 
colleges in response to a change in employment conditions in the related occupational field, while $\beta_{1}+\beta_{2}$ captures the effect of changes in employment conditions at FPCs. The parameter $\beta_{2}$ is the differential effect. If this coefficient is positive, it indicates that student enrollment or degree completion in a field of study at FPCs is more likely to expand in response to positive employment conditions in the related occupations than is the case at public two-year institutions. An F-test statistically validates whether the effect at FPCs is statistically different from zero, i.e., whether $\beta_{1}+\beta_{2}$ is statistically different from zero.

The specification then captures overall shifts of students across for-profit and public institutions, as well as shifts across majors within each institution's type. Given that states clearly differ in the penetration of FPCs and in overall trends in enrollment and that students may become more or less responsive to employment conditions over time in their choices of majors, we report results from two alternative specifications. The first specification includes occupational field fixed effects, school-type-by-year fixed effects, school-typeby-state fixed effects, and state-level control variables. The school-type-by-state fixed effects account for permanent differences in community colleges and FPCs across states. For example, in the data, FPCs in rural states tend to have less penetration than in more populous states. Additionally, these fixed effects also address differences in state-level financing of public schools, average tuition differences across states, and average tuition differences across the type of institutions. The school-type-by-year fixed effects account for any common economy-wide effects in a given year. For example, the effect of the U.S. business cycle would be absorbed by these fixed effects. In addition, they account for common shocks to all FPCs in a given year or common shocks to public institutions in a given year. Thus, only occupational field-specific changes in employment condition at the state-level remain. The error term, $\varepsilon_{i j s t}$, is clustered at the state level. ${ }^{16}$

The second specification includes the most flexible fixed effects, school-type-by-state-by-year fixed effects, $\mathrm{FPC}_{i} \times \mu_{s t}$. In this specification, state-level variables are excluded due to collinearity with the fixed effects. These fixed effects assure that the results identify the effect of changes in relative employment conditions within occupational fields in a given state and year. Consequently, any potential omitted variable bias is mitigated due to the large number of permanent and time-varying variables that can be accounted for in this framework. The error term is again clustered at the state-level. This is our preferred model specification.

\section{Data}

Three main sources of data are used to construct the panel datasets. First, the enrollment regressions rely on data from the restricted-access versions of the National Postsecondary Student Aid Study (NPSAS) conducted by the National Center for Education Statistics collected during the 1999-2000,

\footnotetext{
16 Given the empirical specification, cluster robust standard errors address correlation within each state. Clustering reduces the likelihood of committing a Type I error, where the null hypothesis that a variable's effect equals zero is rejected when it is actually true for the population (see Kézdi, 2004)
}

2003-2004, and 2007-2008 school years. ${ }^{17}$ The survey is a stratified random sample of students enrolled in Title IV eligible postsecondary institutions throughout the United States. Title IV eligible institutions are those that meet federal eligibility requirements to receive federal student financial aid. ${ }^{18}$ We use the NPSAS sampling weights to construct state-level representative samples. We restrict the sample to students pursuing an Associate's degree at either FPCs or two-year public institutions. Given that we study the Associate's degree level, requiring institutions to be Title IV eligible is not binding, i.e., almost all higher education institutes that offer Associate's and Bachelor's degrees are Title IV eligible.

The data include demographic, background, and financial information for students and their families. Importantly, the geographic data is based on the residence of the student, as opposed to the location of their university, a distinction that is particularly important given the prominence of online instruction at for-profit colleges. Overall, the NPSAS sample includes 53,800 students enrolled during the sample period, with 46,400 students at public community colleges and 7,390 students at FPCs.

Second, the degree completion data are provided by the Integrated Postsecondary Education Data System (IPEDS Data Center (2012)) for similar school years as the NPSAS. This is a comprehensive survey of Title IV higher education institutions in the United States. The IPEDS data have the advantage of reporting the universe of college completers at these institutions, which is particularly useful in the early 2000s when the penetration of FPCs was lower. However, demographic data is limited to race and gender compositions of institutions and is compiled based on the institution location rather than student location. Overall, the IPEDS data include $1,581,264$ students who completed an Associate's degree and whose fields of study were reported, with 1,418,909 earned at community colleges and 162,355 earned at for-profit colleges.

Third, occupation data are provided by the Bureau of Labor Statistics (BLS)' Occupational Employment Statistics (OES) from 1997 through 2008. ${ }^{19}$ The OES reports state-level annual employment counts in designated occupations and the mean hourly wage. These wages are deflated to 2008 dollars using the GDP deflator provided by the Bureau of Economic Analysis. Additional information on local area unemployment rates are provided by the Bureau of Labor Statistics' Local Area Unemployment Statistics (LAUS) and real per capita income

\footnotetext{
17 The sampling framework is based on the 2000-2001 Integrated Postsecondary Education Data System files and stratifies institutions by institutional control, institutional level, highest level of offering, Carnegie classification, and state. Weights are then constructed based on probabilities proportional to institutions sampled. Because the NPSAS sampling frame is based on the IPEDS files, neither represent non-Title IV institutions well. See National Postsecondary Student Aid Study (2000, 2004, and 2008) for further details.

${ }^{18}$ Enrollment observations are rounded to the nearest 10 s place as per restricted-use data license.

19 Prior to 1999 , the BLS classified occupations on a slightly less disaggregate level. Data from 1997 and 1998 have been aggregated to the current classification (see http://www.bls.gov/oes/1999/g_itsoc.pdf for further details). Two data anomalies appeared during the construction of the employment conditions. The total employment in the Arts/Communications and Community, Social Services, and Protective Services fields during 1999 and the Physical Science field during 2004 experienced unrealistic increases. In both cases, the average of the previous and next year are substituted.
} 
(in 2008 dollars) is provided by the Bureau of Economic Analysis (BEA). Lastly, we construct the annual number of public institutions per 1 million residents in each state using higher education institutional data from IPEDS and population data from the U.S. Census. We use this as a measure of community college access. ${ }^{20}$

To capture the responsiveness of enrollment and degree completion in majors across FPCs and community colleges, ideally the analysis would map Associate's degree college majors to the most common subsequent occupations chosen by students with those majors. However, no such mapping exists for education attainment at the Associate's level. ${ }^{21}$ Instead, similar to Lang and Weinstein (2013), we use the Classification of Instructional Programs (CIP 2000) from the National Center for Education Statistics (NCES). The NCES and BLS jointly provide a crosswalk for these CIP codes and SOC occupation codes, where the program of study is a direct preparation for an occupational group. ${ }^{22}$ We use this crosswalk to construct a correspondence between two-year college majors and broad occupational fields. We aggregate occupations into 12 related employment fields using the two-digit SOC occupation codes given by the BLS and then map majors into these fields using the related two-digit CIP codes. The complete mapping is provided in Supplementary Appendix Table A1. A few of these fields map a single CIP code to a single two-digit SOC occupation code. For example, the education field maps majors with CIP code 13 (education) to SOC code 25 (education, training, and library occupations); the legal field maps CIP code 22 (legal professions and studies) with SOC code 23 (legal occupations). Others, like the Life and physical science field, map a group of majors (CIP codes 3, 26, 40 , and 41) to a single SOC occupational group (SOC 19 life and physical science occupations). Other fields are defined as a combination of SOC occupations when students might seek employment in various occupations (e.g., the business field maps majors with CIP code 51 (business, management, marketing, and related supporting services majors) with four related SOC codes (11: management, 13: business and financial operations, 41: sales and related, and 43: office and administrative support occupations). Most of these mappings are fairly unambiguous. It is important to note that a student in a given major might not obtain employment in an occupation related to their degree, but arguably the major and institution choices were related to their ideal career aspirations when entering college.

One challenge with the mapping is that the CIP code for liberal arts degrees corresponds with liberal arts teaching occupations, but liberal arts students are typically employed in a broader range of occupations. Accordingly, the liberal

\footnotetext{
20 This measure is constructed with the entire population as the denominator, rather than the population of young people. This is due to the fact that community colleges and FPCs tend to attract high proportions of nontraditional aged students-both students still of high school age as well as students returning to school at later stages in their career.

21 One potential mapping is provided by the U.S. Census' American Community Survey (ACS), but this is only for Bachelor's degrees. This mapping would require a critical assumption that individuals earning an Associate's degree and a Bachelor's degree would go into similar occupations. This seems highly unlikely.

22 See the 1998 Standard Occupational Classification Files (1998) and Occupation-to-Training Classification for further details.
}

arts majors are assigned to a liberal arts field and the corresponding occupations are those in the social sciences, community and social services, legal, education, and services, as reported in Supplementary Appendix Table A1. This field is potentially problematic given the substantial share of community college students enrolled in liberal arts or general education programs. Empirical robustness checks verify that the main results remain even after removing this substantial group of students (see Supplementary Table A4 for a comparison of results).

Given the mapping of majors and occupations to employment fields, we aggregate individuals using the NPSAS data to obtain the annual total enrollment in each field of study by school type for each state and aggregate institutions using the IPEDS data to obtain the annual total degrees completed in each field of study by school type for each state, $Y_{i j s t}$. This aggregation incorporates both the choice of college (for profit or community college) as well as the choice of major. We also construct similarly the annual total enrollment (and degrees completed) for each state, $T_{\text {st }}$. Using these aggregates allows an analysis of the distribution of students across schools and majors in response to changes in related labor market conditions while controlling for overall changes in the number of students seeking or who have completed an Associate's degree. For example, the specifications provide evidence as to whether increases in enrollment in health-related majors is related to increases in employment in the health field in California and how the rate of increase differs between for-profit colleges and community colleges.

The main specifications only include the observation with positive enrollment or degree completions and exclude the zero observations. That is, the estimated effects are conditional on there being some enrollment or degree completions in majors related to a given field at a specific school type. The assumption is that if there are no programs offered in a particular field in a state at a given school type, enrollment and degree completions cannot respond to employment conditions. Subsequent robustness checks will extend the main specification and analyze how including zeros effects the estimation.

Supplementary Appendix Table A2 provides descriptive statistics on the total enrollment and degrees completed during the last decade across school types and fields at the national level. This table indicates that Liberal Arts majors at community colleges are the most popular two-year degree. Community colleges and FPCs both enroll substantial shares of their student bodies in health related majors, while business majors have become increasingly popular at FPCs.

The empirical analysis examines the effect of employment conditions in occupations that typically require an Associate's degree. The BLS' 2012-2013 Occupational Outlook Handbook reports educational attainment by SOC occupation code (see Occupational Outlook Handbook (2012)). In the main analysis, occupations are included if less than half of the workers hold a Bachelor's degree or higher but more than half hold a high school diploma. This excludes occupations with high educational attainment requirements (e.g., doctors, lawyers, and teachers) and those with low education attainment requirements (e.g., shampooers and garbage collectors). Included occupations are those that a graduate with an Associate's degree is likely to pursue, such as nursing, recreational therapy, paralegal, and teacher's assistant. 
Source: Author calculations based on Integrated Postsecondary Education Data System (IPEDS).

\begin{tabular}{|c|c|c|c|c|c|c|c|c|}
\hline & \multicolumn{4}{|c|}{ Community college } & \multicolumn{4}{|c|}{ For-profit college } \\
\hline & Mean & $\begin{array}{l}\text { Standard } \\
\text { deviation }\end{array}$ & Minimum & Maximum & Mean & $\begin{array}{l}\text { Standard } \\
\text { deviation }\end{array}$ & Minimum & Maximum \\
\hline \multicolumn{9}{|c|}{ Dependent variables } \\
\hline Enrollment per field & 9456.4 & $19,925.2$ & 0.0 & $255,959.0$ & 788.8 & 2421.5 & 0.0 & $27,677.3$ \\
\hline $\begin{array}{l}\text { Degree completion } \\
\text { per field }\end{array}$ & 779.8 & 2693.7 & 0.0 & $55,775.0$ & 83.0 & 254.8 & 0.0 & 3269.0 \\
\hline \multicolumn{9}{|c|}{ Independent variables $^{\mathrm{a}}$} \\
\hline Total enrollment & $162,096.0$ & $191,826.5$ & 1.8 & $1,138,946.0$ & $162,096.0$ & $191,826.5$ & 1.8 & $1,138,946.0$ \\
\hline $\begin{array}{l}\text { Total degrees } \\
\text { completed }\end{array}$ & $10,376.5$ & $13,454.6$ & 24.0 & $90,857.0$ & $10,376.5$ & $13,454.6$ & 24.0 & $90,857.0$ \\
\hline $\begin{array}{l}\text { Unemployment rate } \\
\text { (in \%) }\end{array}$ & 4.67 & 1.12 & 2.53 & 7.67 & 4.67 & 1.12 & 2.53 & 7.67 \\
\hline $\begin{array}{l}\text { Community colleges } \\
\text { per } 1 \text { million } \\
\text { residents }\end{array}$ & 5.05 & 3.13 & 0.00 & 14.18 & 5.05 & 3.13 & 0.00 & 14.18 \\
\hline $\begin{array}{l}\text { Log real income (per } \\
\text { capita) }\end{array}$ & 0.32 & 4.18 & 0.03 & 67.19 & 0.32 & 4.18 & 0.03 & 67.19 \\
\hline$\%$ Asian & 3.99 & 10.28 & 0.00 & 73.95 & 3.99 & 10.28 & 0.00 & 73.95 \\
\hline$\%$ Black & 8.91 & 8.35 & 0.00 & 37.31 & 8.91 & 8.35 & 0.00 & 37.31 \\
\hline \% Hispanic & 5.39 & 7.09 & 0.00 & 36.16 & 5.39 & 7.09 & 0.00 & 36.16 \\
\hline$\%$ Female & 61.72 & 6.54 & 37.31 & 80.00 & 61.72 & 6.54 & 37.31 & 80.00 \\
\hline \multicolumn{9}{|c|}{ Labor market condition measures } \\
\hline \multicolumn{9}{|l|}{ Employment growth } \\
\hline AA occupations & 2.95 & 10.31 & -44.18 & 81.51 & 2.95 & 10.31 & -44.18 & 81.51 \\
\hline BA+ occupations & 2.0 & 12.3 & -48.0 & 148.9 & 2.0 & 12.3 & -48.0 & 148.9 \\
\hline All occupations & 2.4 & 4.5 & -28.8 & 30.8 & 2.4 & 4.5 & -28.8 & 30.8 \\
\hline \multicolumn{9}{|l|}{ Hourly Wage } \\
\hline AA occupations & 19.03 & 5.34 & 8.63 & 41.04 & 19.03 & 5.34 & 8.63 & 41.04 \\
\hline BA+ occupations & 29.81 & 9.90 & 11.63 & 68.84 & 29.81 & 9.90 & 11.63 & 68.84 \\
\hline All occupations & 23.63 & 7.75 & 8.90 & 55.50 & 23.63 & 7.75 & 8.90 & 55.50 \\
\hline
\end{tabular}

Notes: Observations are total number of students in a particular state and year in an occupational field (see Supplementary Table A2) at a specific school type (community college or for-profit college).

a State-level data. AA occupations: Includes occupations where at least $50 \%$ of workers hold a high school degree and less than $50 \%$ of workers hold a Bachelor's degree or higher. This is the baseline specification group. $B A \pm$ occupations: Includes occupations where more than $50 \%$ of workers hold a Bachelor's degree or higher. All occupations: All occupations regardless of workers' educational attainment. Hourly wages are in 2008 dollars.

That is, the employment conditions (namely, employment growth and the real wage level) in a field are calculated as

$E C_{j s t}=\sum_{k=1}^{K} \omega_{j s t}^{k} \times \bar{o}_{j s t}^{k} \times I\left(k \in \Omega_{j}\right)$

where $\omega_{j s t}^{k}$ is the share weight in employment field $j$ in occupation $k$ in state $s$ during year $t, t, \bar{o}_{j s t}^{k}$ is the three-year average employment growth or real wage level during year $t, t-1$, and $t-2$ in occupation $k$ in state $s$, and $I$ is an indicator function to whether occupation $k$ is an element of the set $\Omega_{j}$. The set $\Omega_{j}$ is defined as the subset of occupations in field $j$ that satisfy the above educational attainment rules. Using the average over a three-year time span permits an evaluation of the changes in employment conditions when the individual was deciding to enroll in the two-year program. Annual national averages are provided for employment growth and hourly wages in 2008 dollars across all fields in Supplementary Appendix Table A3.

Subsequent robustness analyses study whether FPC and community college students respond differently to labor market conditions by including occupations where more than half of all workers hold a Bachelor's degree or higher and another with all occupations regardless of workers' educational attainment. This will be especially important for community college students as some of them use two-year programs as an initial step towards obtaining a Bachelor's degree and consider the employment conditions of occupations requiring a Bachelor's degree when enrolling in programs at the Associate's degree level.

\section{Results}

The descriptive statistics summarizing all variables in the regressions are provided in Table 1 and indicate that the average annual number of majors enrolled in a given field of study at community colleges is 9456 per state, while the average is 789 at FPCs. This is due to the overall larger share of students enrolled in community colleges. [Note that throughout, student sampling weights are used for the NPSAS sample to ensure representativeness.] Similarly, the table indicates that the average annual number of degrees completed is 780 at community colleges and 83 at FPCs. The table also indicates that there is substantial variation in these totals across fields.

Table 2 reports the coefficients of interest from the estimation approaches outlined above for student enrollment. Table 3 reports parallel regressions with degree completion as the dependent variable. Because employment growth and wages are likely related, we report specifications that include each separately, as well as jointly. The first three 
Table 2

Effect of changes in employment growth and wages on student enrollment.

\begin{tabular}{|c|c|c|c|c|c|c|}
\hline & 1 & 2 & 3 & 4 & 5 & 6 \\
\hline Employment growth & $\begin{array}{c}-0.006^{* *} \\
(0.003)\end{array}$ & & $\begin{array}{c}-0.004 \\
(0.003)\end{array}$ & $\begin{array}{c}-0.006^{* *} \\
(0.003)\end{array}$ & & $\begin{array}{r}-0.005^{*} \\
(0.003)\end{array}$ \\
\hline Employment growth $\times$ FPC & $\begin{array}{c}0.039^{* * * *} \\
(0.011)\end{array}$ & & $\begin{array}{c}0.037^{* * * *} \\
(0.0111)\end{array}$ & $\begin{array}{c}0.039^{* * *} \\
(0.010)\end{array}$ & & $\begin{array}{l}0.037^{\text {*** }} \\
(0.010)\end{array}$ \\
\hline Real wage & & $\begin{array}{l}0.040^{* * * *} \\
(0.010)\end{array}$ & $\begin{array}{l}0.040^{* * * *} \\
(0.010)\end{array}$ & & $\begin{array}{c}0.033^{* *} \\
(0.012)\end{array}$ & $\begin{array}{c}0.032^{* *} \\
(0.012)\end{array}$ \\
\hline Real wage $\times$ FPC & & $\begin{array}{l}(0.012) \\
(0.012)\end{array}$ & $\begin{array}{l}(0.012) \\
(0.012)\end{array}$ & & $\begin{array}{l}(0.012) \\
(0.012)\end{array}$ & $\begin{array}{l}(0.012) \\
(0.012)\end{array}$ \\
\hline$N$ & 2188 & 2188 & 2188 & 2188 & 2188 & 2188 \\
\hline$R^{2}$ & 0.69 & 0.69 & 0.69 & 0.74 & 0.74 & 0.74 \\
\hline $\begin{array}{l}P \text {-value from } F \text {-test that employ. growth }+ \text { employ. growth } \times \mathrm{FPC}=0 \\
P \text {-value from } F \text {-test that real wage }+ \text { real wage } \times \mathrm{FPC}=0\end{array}$ & 0.00 & 0.00 & $\begin{array}{l}0.00 \\
0.00\end{array}$ & 0.00 & 0.00 & $\begin{array}{l}0.00 \\
0.01\end{array}$ \\
\hline Occupational field fixed effects & Yes & Yes & Yes & Yes & Yes & Yes \\
\hline School type-by-year fixed effects & Yes & Yes & Yes & No & No & No \\
\hline School type-by-state fixed effects & Yes & Yes & Yes & No & No & No \\
\hline State-level control variables & Yes & Yes & Yes & No & No & No \\
\hline School-type-by-state-by-year fixed effects & No & No & No & Yes & Yes & Yes \\
\hline
\end{tabular}

Notes: Asterisks *, ${ }^{* *}$, and ${ }^{* * *}$ indicate significance at the $10 \%, 5 \%$, and $1 \%$ statistical levels, respectively. Standard errors are clustered by state and listed beneath the coefficient estimates. Control variables include the unemployment rate, community colleges per 1 million residents, per capita income, percent female, and percentages of students by race (whites excluded). Baseline specification group of occupations where at least 50\% of workers hold a high school degree and less than $50 \%$ of workers hold a Bachelor's degree or higher are used to construct employment growth and wages. $P$-values from $F$-tests that employ. growth + employ. growth $\times \mathrm{FPC}=0$ and real wage + real wage $\times \mathrm{FPC}=0$ in all cases are $1 \%$ or less.

Table 3

Effect of changes in employment growth and wages on degree completion.

\begin{tabular}{|c|c|c|c|c|c|c|}
\hline & 1 & 2 & 3 & 4 & 5 & 6 \\
\hline Employment growth & $\begin{array}{c}-0.002 \\
(0.002)\end{array}$ & & $\begin{array}{c}-0.002 \\
(0.002)\end{array}$ & $\begin{array}{r}-0.001 \\
(.003)\end{array}$ & & $\begin{array}{c}-0.001 \\
(0.003)\end{array}$ \\
\hline Employment growth $\times$ FPC & $\begin{array}{c}0.013^{*} \\
(0.007)\end{array}$ & & $\begin{array}{c}0.013^{*} \\
(0.007)\end{array}$ & $\begin{array}{c}0.016^{*} \\
(0.009)\end{array}$ & & $\begin{array}{r}0.016^{*} \\
(0.009)\end{array}$ \\
\hline Real wage & & $\begin{array}{c}0.002 \\
(0.015)\end{array}$ & $\begin{array}{c}0.001 \\
(0.016)\end{array}$ & & $\begin{array}{c}0.002 \\
(0.016)\end{array}$ & $\begin{array}{c}0.001 \\
(0.017)\end{array}$ \\
\hline Real wage $\times$ FPC & & $\begin{array}{c}0.002 \\
(0.013)\end{array}$ & $\begin{array}{c}0.001 \\
(0.014)\end{array}$ & & $\begin{array}{c}0.003 \\
(0.014)\end{array}$ & $\begin{array}{c}0.001 \\
(0.014)\end{array}$ \\
\hline$N$ & 2397 & 2397 & 2397 & 2397 & 2397 & 2397 \\
\hline$R^{2}$ & 0.70 & 0.70 & 0.70 & 0.72 & 0.72 & 0.72 \\
\hline$P$-value from $F$-test that employ. growth + employ. growth $\times \mathrm{FPC}=0$ & 0.10 & & 0.12 & 0.10 & & 0.11 \\
\hline$P$-value from $F$-test that real wage + real wage $\times \mathrm{FPC}=0$ & & 0.83 & 0.92 & & 0.81 & 0.90 \\
\hline Occupational field fixed effects & Yes & Yes & Yes & Yes & Yes & Yes \\
\hline School type-by-year fixed effects & Yes & Yes & Yes & No & No & No \\
\hline School type-by-state fixed effects & Yes & Yes & Yes & No & No & No \\
\hline State level control variables & Yes & Yes & Yes & No & No & No \\
\hline School-type-by-state-by-year fixed effects & No & No & No & Yes & Yes & Yes \\
\hline
\end{tabular}

Notes: Asterisks * , **, and ${ }^{* * *}$ indicate significance at the $10 \%, 5 \%$, and $1 \%$ statistical levels, respectively. Standard errors are clustered by state and listed beneath the coefficient estimates. Control variables include the unemployment rate, community colleges per 1 million residents, per capita income, percent female, and percentages of students by race (whites excluded). Baseline specification group of occupations where at least $50 \%$ of workers hold a high school degree and less than $50 \%$ of workers hold a Bachelor's degree or higher are used to construct employment growth.

columns include occupational field fixed effects, schooltype-by-year fixed effects, school-type-by-state fixed effects and a variety of state level control variables. The final three columns report results containing occupational field fixed effects and school-type-by-state-by-year fixed effects. $^{23}$

The first three columns of Tables 2 and 3 indicate a very small negative correlation between a field's employment growth and the enrollment and degrees completed in majors for related fields of study at community colleges, but the

\footnotetext{
${ }^{23}$ Alternative specifications using various subsets of these fixed effects produce consistent results.
}

estimate is statistically imprecise for degrees completed. The point estimate for FPCs, however, is positive and significant: a $1 \%$ increase in employment growth in a field is correlated with a 3.3 percentage point increase in student enrollment and a 1.1 percentage point increase in degree completion. Additionally, F-tests indicate that the correlation between employment growth and FPC enrollment is statistically significant at $1 \%$, while the correlation between employment growth and FPC degree completion is statistically significant at $11 \%$.

Real wages are moderately related to student enrollment, although the effect of wages on student enrollment is larger at FPCs than at public colleges. Specifically, a $1 \%$ increase in real wages is associated with a $4.0 \%$ increase in enrollment at public institutions, but a 5.9-6.4 percentage point increase 
at FPCs. When both wages and employment growth are included in the same regression, the additional effect at FPCs is not estimated as precisely. Wages are not statistically associated with degree completions at either type of college.

As discussed in previous sections, these specifications account for a number of fixed effects and state level control variables, but do not allow for common shocks to school types in a year and state-for example, a common increase in all FPCs in California in 2008. The final three columns include school-type-by-year-by-state fixed effects to allow for these common unobserved characteristics. For example, they control for differences in the penetration of FPCs relative to community colleges in different states and in different years. The variation remaining that identifies the model is the variation in the relative growth of specific fields of study across institution types.

The last three columns of Tables 2 and 3 presents results of the second specification and are consistent with the first specification (results provided in the first three columns of Tables 2 and 3). There is a significantly negative but small effect of employment growth in a field on the share of enrollment in related majors in community colleges, and no effect on majors' shares of degree completion. Similar to previous specification estimates, there is a much larger and positive correlation between employment growth and enrollment and degree completion at FPCs: a 1\% increase in employment growth in a field is correlated with an approximate 3.2 percentage point increase in enrollment and a 1.5 percentage point increase in degree completion in related majors. The effect of wages also are similar in these specifications, with about a 2 percentage point larger impact on enrollment at FPCs, although this is not always statistically significant. Again, while these estimated responses appear to be large, the magnitude of the results indicate a change in flow of new hires within occupations; although new hires are a small proportion of total employment, entrants with new degrees may be a substantive share of new hires.

The main results suggest that enrollment and degree completion in majors at FPCs are more responsive to changes in related employment conditions than at community colleges. We test the strength of this relationship using a series of robustness checks. These are all detailed in the online Supplementary Appendix 2.

First, as noted, the liberal arts field is much larger at community colleges than at for profit colleges, and has a broader match to related occupations. We drop the liberal arts field to see if this affects the findings. The results from this estimation are provided in Supplementary Table 4. A second concern is that we have a high proportion of observations with zero enrollment or degree completions at either community colleges or FPCs. Supplementary Table 5 provides alternative estimation approaches for dealing with this problem, again described in the online appendix. Third, we examine whether the results are driven by sensitivity to different labor markets. Community college programs are often designed to enable students to advance to four-year public institution to obtain a Bachelor's degree. There is lower responsiveness at community colleges to labor market conditions for occupations requiring an Associate's degree, but is this true for general labor markets conditions or occupations requiring a Bachelor's degree? The online appendix Table 6 reports these robust- ness checks. Finally, we examine whether the results vary by students' race or for men and women, with results in Supplementary Tables 7 and 8 . In general, the baseline pattern of results is confirmed in all of these instances, with larger effects of labor market conditions at FPCs, and more muted or statistically insignificant results at community colleges.

\section{Conclusion}

For-profit colleges have been increasingly scrutinized for their high tuition rates, low graduation rates, and their students' high debt burdens upon graduation (see Allison, 2014; Editorial, 2012; Matthews, 2012; Porter, 2014; Stiglitz, 2012; Webley, 2012). However, these institutions have grown much more rapidly than other institutions of higher education. This is particularly true in the two-year higher education market, where student enrollment rates at FPCs have grown six times faster than at public community colleges and where FPCs currently account for almost a quarter of all Associate's degrees awarded.

The rapid shift in enrollment has occurred even with more limited program offerings at many two-year FPCs. However, FPCs may have an advantage over community colleges in terms of structural features that may allow them to more easily adjust their course offerings in response to changing employment conditions. Community colleges are more likely to have decentralized faculty governance systems with tenured professors, to have financial support that is tied to local voter support, and to have large campuses with high capital costs. For-profit colleges tend to have more part-time faculty, more centrally administered decision making, to lease or rent space, to rely more on online courses, and to have fewer constraints when it comes to expanded and removing courses of study.

The empirical analysis examines Associate's degree student enrollment and degree completion in various majors at community colleges and FPCs. The results indicate that FPCs have expanded their enrollment and degree completion rapidly in majors where employment conditions in related occupations are improving and have decreased enrollment in majors where employment conditions in related occupations are diminishing. The estimates suggest that a $1 \%$ higher employment growth rate in occupations in a given employment field in a state is correlated with a 3.2 percentage point increase in students enrolled in FPCs in the state in related majors. The student enrollment share at community colleges majors is much less responsive. Additionally, a 1\% higher real wage is associated with approximately a 3.2 percentage point higher enrollment in related majors at community colleges but an effect that is about a third larger at for-profit colleges. Finally, the effects on degree completions are somewhat smaller for both FPCs and community colleges in response to changes in employment growth and wages, but again show the same pattern of larger positive effects at FPCs and smaller, sometimes negative, and insignificant effects at community colleges. These results are robust to a variety of flexible specifications of fixed effects for employment fields and school types, differential penetration of FPCs, separate segments of the employment market based on education levels, and for students of different demographic characteristics. 
The results are unable to distinguish whether the higher responsiveness is due to the unobserved attributes of the students who are most attracted to FPCs or due to the institutional features of the FPCs themselves. Any change in enrollment requires action of both students and institutions. Furthermore, even if FPCs are more nimble in expanding enrollment than public competitors, there may be other changes occurring when institutions adjust their program offerings, such as a decline in quality. This quantity-quality trade-off may be particularly salient when expanding enrollment rapidly, especially when increasing enrollment in non-existent or smaller programs. Future work should evaluate the institutional nuances and other dynamic interactions that may have occurred during periods of rapid expansion.

\section{Supplementary materials}

Supplementary material associated with this article can be found, in the online version, at doi:10.1016/j.econedurev.2014.11.004.

\section{References}

About ASU. (2012). Arizona State University. http://about.asu.edu/ facts.html.

Allison, T. (2014, May 14). Why the Feds should regulate for-profit colleges. Huffington Post.

Apollo Group Inc. (2011). Reports fiscal 2011 fourth quarter and year end results Apollo Group, Inc. http://investors.apollogrp.edu/ phoenix.zhtml?c=79624\&p=irol-newsArticle\&id=1618736.

Bailey, T. (2006). Increasing competition and growth of the for-profits. In T. Bailey, \& V. S. Morest (Eds.), Defending the community college equity agenda (pp. 87-109). Baltimore: Johns Hopkins University Press.

Bennett, D., Lucchesi, A., \& Vedder, R. (2010). For profit higher education: Growth, innovation, and regulation (Policy paper) Center for College Affordability and Productivity.

Berger, M. C., \& Kostal, T. (2002). Financial resources, regulation, and enrollment in US public higher education. Economics of Education Review, 21(2), 101-110.

Betts, J. (1996). What do students know about wages? Evidence from a survey of undergraduates. Journal of Human Resources, 31(1), 27-56.

Betts, J., \& McFarland, L. (1995). Safe port in a storm: The impact of labor market conditions on community college enrollments. Journal of Human Resources, 30(4), 741-765.

Black, S., \& Su, A. (2002). Who goes to college? Differential enrollment by race and family background (NBER working paper no. 9310).

Card, D., \& Kruegar, A. (1996). School resources and student outcomes: An overview of the literature and new evidence from North and South Carolina. Journal of Economic Perspectives, 10, 31-50.

Cellini, S. (2005). Community colleges and proprietary schools: A comparison of sub-baccalaureate postsecondary institutions (Working paper 05-012) California Center for Population Research (CCPR).

Cellini, S. (2009). Crowded colleges and college crowd-out: The impact of public subsidies on the two-year college market. American Economic Journal: Economic Policy, 1(2), 1-30.

Cellini, S. (2012). For-profit higher education: An assessment of costs and benefits. National Tax Journal, 65, 153-180.

Cellini, S., \& Chaudhary, L. (2012). The labor market returns to a for-profit college education (NBER working paper no. 18343).

Chung, A. (2008). For-profit student heterogeneity (Unpublished manuscript). Ann Arbor, MI: University of Michigan.

Chung, A. (2012). Choice of for-profit college. Economics of Education Review, $31,1084-1101$
Community College Fact Sheet. (2012). American Association of Community Colleges. http://www.aacc.nche.edu/AboutCC/Documents/ FactSheet2012.pdf.

Dellas, H., \& Sakellaris, P. (2003). On the cyclicality of schooling: Theory and evidence. Oxford Economic Papers, 55(1), 148-172.

Deming, D., Goldin, C., \& Katz, L. (2012). The for-profit postsecondary school sector: Nimble critters or agile predators? The Journal of Economic Perspectives, 26(1), 139-163.

Darolia, R., Koedel, C., Martorell, P., \& Perez-Arce, F. (2014). Do employers prefer workers who attend for-profit colleges? Evidence from a field experiment (RAND working paper WR-1054).

Digest of Education Statistics (2012). U. S. Department of Education, National Center for Education Statistics, NCES 2012001. http://nces.ed.gov/ pubs2012/2012001.pdf.

Digest of Education Statistics (2013). U. S. Department of Education, National Center for Education Statistics, NCES 2014015. http://nces.ed.gov/ pubs2014/2014015.pdf.

Editorial (2012). Editorial false promises. New York Times.

Freeman, J., \& Hirsch, B. (2008). College majors and the knowledge content of jobs. Economics of Education Review, 27, 517-535.

Hentschke, G. (2011). For profit sector innovations in business models. In B. Wildavsky, A. Kelly, \& K. Carey (Eds.), Reinventing higher education: The promise of innovation (pp. 159-196). Cambridge: Harvard Education Press.

IPEDS Data Center. (2012). U.S. Department of Education, National Center for Education Statistics. http://nces.ed.gov/ipeds/datacenter/.

Kézdi, G. (2004). Robust standard error estimation in fixed-effects models. Hungarian Statistical Review, 9, 95-116.

Kinser, K. (2007). Dimensions of corporate ownership in for-profit higher education. The Review of Higher Education, 30(3), 217-245.

Knapp, L., Kelly-Reid, J., \& Ginder, S. (2011). Postsecondary institutions and price of attendance in the United States: 2010-2011, degrees and other awards conferred: 2009-2010, and 12-month enrollment: 20092010. U.S. Department of Education, National Center for Education Statistics.

Kofoed, M. (2014). For-profit and traditional colleges: Institutional control and financial aid allocation (Working paper).

Lang, K., \& Weinstein, R. (2012). Evaluating student outcomes at for-profit colleges (NBER working paper 18201).

Lang, K., \& Weinstein, R. (2013). The wage effect of not-for-profits and for-profit certifications: Better data, somewhat different results. Labour Economics, 24(C), 230-240.

Liu, V., \& Belfield, C. (2014). The labor market returns to for-profit higher education: Evidence for transfer students (CAPSEE working paper).

Matthews, D. (2012, July 30). Harkin: For-profit colleges a terrible deal. The Washington Post.

Moffit, R. (1995). Selection bias adjustment in treatment-effects models as a method of aggregation. Proceedings of the American Statistical Association, 234-238.

National postsecondary student aid study, 2000, 2004, and 2008. U.S. Department of Education, National Center for Education Statistics.

Occupation-to-training classification. Crosswalks: SOC to CIP. National Crosswalk Service Center. http://www.xwalkcenter.org/index.php/ classifications/crosswalks.

Occupational outlook handbook. (2012). U.S. Department of Labor, Bureau of Labor Statistics. Table 1.11. http://bls.gov/emp/ep_table_111.htm.

Porter, E. (2014, February 25). The bane and the boon of for-profit colleges. New York Times.

Sakellaris, P., \& Spilimbergo, A. (2000). Business cycles and investment in human capital: International evidence on higher education. CarnegieRochester Conference Series on Public Policy, 52(1), 221-256.

Standard occupational classification files. (1998). National Crosswalk Service Center. http://webdata.xwalkcenter.org/ftp/download/soc1998/ socoes98.xls.

Stiglitz, J. (2012, July 3). Debt buries American dream. USA Today.

Turner, S. (2003). For-profit colleges and non-traditional students: Responses to cyclical shocks (Working paper) National Center for the Study of Privatization in Education.

Webley, K. (2012, January 9). For-profit schools: ‘Agile predators' or just business savy?. TIME Magazine.

Webbink, D., \& Hartog, J. (2004). Can students predict starting salaries? Yes! Economics of Education Review, 23(2), 103-113. 